\title{
Pemilihan Kepala Daerah Secara Langsung: Solusi atau Masalah?
}

\author{
Warsito Utomo
}

The succes of general election either is carried out in direct system or indirect system, will be determined by all of election components such as society, politic al elites and power elites. The elections is the instrument of democracy to reach the good governance to achieve the good society, state and regional autonomy. The direct presidential election will show that people' choice is the manifestation of soveregnity of the people to determine who will be the chief of the nation. In the modern democracy, the most important aspect of the integration of nation is constitution. The presidential direct election is just one the mechanisme to measure how good the democration system run.

S ejak bergulinnya reformasi di tahun 1998 banyak perubahan yang terjadi didalam perpolitikan maupun pemerintahan di Indonesia. Di bidang politik, Era Reformasi diawali dengan "ditumbangkannya" Presiden Soeharto yang kemudian digantikan oleh BJ Habibie sebagai Presiden yang ke III. Pada pemerintahan Habibie dilaksanakan PEMILU yang ke VIII yang sangat berbeda dengan Pemilu-Pemilu di Era Orde Baru yang berlangsung mulai tahun 1971 sampai dengan 1997 yang hanya didominir oleh 2 Partai dan 1 Golongan. Pemilu 1999 diikuti oleh 48 Partai dengan cara pembagian kursi yang sangat berbeda dengan Pemilu-Pemilu sebelumnya. Dengan digantikannya Presiden BJ Habibie oleh Abdurrachman Wahid di tahun 1999 sebagai Presiden ke $\mathrm{IV}$, dan dalam waktu sangat singkat 2 tahun kemudian di tahun 2001 digantikan oleh Megawati Soekarnoputri sebagai Presiden Indonesia yang $k e V$, nampak sekali bahwa Reformasi di Indonesia hanyalah sebatas
Reformasi Struktur. Banyak hal yang menyeleweng dari makna dicanangkannya Reformasi, sehingga pelaksanaan Reformasi dianggap tidak mengenai sasaran, amburadul dan tidak mengarah. Reformation much discussed but seldom enacted.

\section{Proses Demokratisasi}

Meskipun tanpa disertai dengan planned change yang matang, perubahan di bidang politik berjalan terus dengan diubahnya Undang-Undang Dasar 1945 sebagai UUD 45 Amandemen. Reformasi di bidang politik bergulir terus dengan diundangkannya UU Politik, LU Partai Politik, demikian juga UU Nomor 12 Tahun 2003 Tentang Pemilu. Perubahan paradigma dari sistem politik dan pemerintahan di Era Orde Baru yang selama itu cenderung monolitik sentralistik yang lebih mengedepankan nuansa otoritarian diganti dengan sistem politik dan pemerintahan di Era 
Reformasi yang lebih bertumpu pada suasana demokratis khususnya di tingkat lokal (local democracy). Penonjolan otoritas diganti dengan penonjolan kompatibilitas didalam kerangka penerapan sistem politik dan pemerintahan yang governance. Dimana pemerintahan tidak lagi merupakan agen tunggal, tetapi sharing kewenangan dengan private dan juga community.

Di bidang pemerintahan disepakati perubahan formulasi dan implementasi Undang-Undang Nomor 5 Tahun 1974 Tentang Pokok-Pokok Pemerintahan Di Daerah menjadi Undang-Undang Nomor 22 Tahun 1999 Tentang Pemerintahan Daerah. Didalam suasana penerapan selama 25 tahun, Undang-Undang Nomor 5 Tahun 1974 Tentang Pokok-Pokok Pemerintahan di Daerah, dimana penerapan dekonsentrasi lebih overshadowing terhadap desentralisasi atau otonomi, maka nampak sekali kurangnya suasana demokratis pemerintahan di daerah-daerah. Dimana kewenangan rakyat yang disalurkan melalui badan legislatip ialah DPRD baik tingkat I maupun tingkat II tidak memiliki makna adanya demokrasi dikarenakan kekuasaan dan kekuatan eksekutif (dalam hal ini Kepala Daerah) menjadi sangat kuat sekali. Dengan diterapkannya dekonsentrasi sama pentingnya dengan desentralisasi, maka kedudukan Gubernur dan/atau Bupati serta Walikota sebayal Wakil Pemerintah Pusat menjadi lebih besar dan kuat daripada sebagai Kepala Daerah. Dengan diundangkannya Undang-Undang Nomor 22 Tahun 1999 Tentang Pemerintahan Daerah, dan Undang-Undang Nomor 25 Tahun 1999 Tentang Perimbangan Keuangan Antara Pusat dan Daerah, dimaksudkan agar supaya demokrasipun terjadi di daerah tidak hanya demokrasi di tingkat nasional. Tetapi didalam implementasinya terjadi bahwa hubungan diantara Pemerintah Pusat dengan Pemerintahan Daerah maupun antar Pemerintahan di daerah, nampak sekali lebih berperspektif the process of political interaction daripada technical administration atau practical administration. Dengan banyaknya pasal-pasal yang multi tafsir atau mis-interpretation, maka penerapan UndangUndang ini menjadi agak kacau. Lebih-lebih Undang-Undang ini masih harus dilengkapi dengan peraturan ataupun ketentuan pelengkapnya yang berjumlah puluhan. Keadaan ini menjadikan makna otonomi. atau desentralisasi menjadi bergeser, antara lain hanya bertitik tekan kepada Uang atau PAD dan/atau DAU, ataupun sekedar perebutan kewenangan atau tarik menarik kepentingan diantara pusat, propinsi, kabupaten dan kota. Tumbuhnya aroganisme daerah yang menjadikan daerah agak tertutup dan juga menimbulkan exclusivisme daerah yang menjurus kepada terjadinya disintegrasi. Demikian pula dikarenakan sosialisasi Undang-Undang ini yang terlalu pendek dan cepat, berakibat adanya anggapan bahwa Undang-Undang ini hanyalah Undang-Undangnya Departemen Dalam Negeri. Akibatnya lebih jauh Departemen atau Instansi Vertikal lainnya tidak merasa terikat dengan diundangkannya Undang-Undang Nomor 22 Tahun 1999 dan 25 Tahun 1999 ini. Disamping juga formulasi Undang - Undang dan makna desentralisasi atau otonomi yang kurang mengakar di daerah. Desentralisasi sekedar diketahui sebagai devolution atau kebebasan, kemerdekaan tanpa adanya keterikatan.

Didalam suasana reformasi yang "demokratis" dengan dikeluarkannya Undang-Undang Nomor 22 Tahun 1999 Tentang Pemerintahan Daerah dan juga Undang-Undang Nomor 25 Tahun 1999 Tentang Perimbangan Keuangan Antara Pusat dengan Daerah serta Peraturan 
Pemerintah (PP) Nomor 84 Tahun 2000 Tentang Pedoman Organisasi Perangkat Daerah dan Peraturan Pemerintah (PP) Nomor 25 Tahun 2000 Tentang Kewenangan. Pemerintah Daerah, maka keberadaan implementasi politik dan pemerintahan di daerah menampakkan hal-hal sebagai berikut :

Pertama, suasana yang demokratis yang mengarah ke suasana euphoria rakyat, menjadikan makna kekuasaan ditangan rakyat yang selama ini kurang dimiliki rakyat, menjadikan rakyat bersuasana anarkhis. Rakyat sering tidak mengakui dan mengabaikan peraturan, hukum, pranatapranata bahkan keberlangsungan lingkungan yang kondusif.

Kedua, secara kelembagaan rakyat khususnya Badan Legislatif atau Dewan Perwakilan Rakyat Daerah menjadikan lembaga yang sarat dengan kekuasaan dan penguasa-penguasa lokal. Dan dengan latar belakang pengetahuan yang minim mengenai fungsi legislatif maka tugas utama yang dilakukan bukannya legislasi tetapi lebih ke pengawasan dan penganggaran. Apabila di Era Orde Baru dikenal adanya "penguasa tunggal" yang terletak pada penguasaan dan kewenangan eksekutif yang demikian besar, maka di Era Reformasi ini, DPRD-lah yang menggantikan suasana tersebut. Sebagai "mitra sejajar" seperti yang dirumuskan didalam Undang-Undang 22 Tahun 1999 diantara Badan Eksekutif dengan Badan Legislatif dengan fungsinya masing-masing menjadi hambar. Dan ini lebih disebabkan oleh hingai bingarnya perumusan dan penerapan demokrasi yang keluar dari track rules of the gamesnya. Dan suasana ini dapat terjadi karena terlalu lamanya penerapan politik dan pemerintahan yang sentralistik monolitik. Akibatnya pemerintahan di daerah tanpa kendali dalam kestrukturan Pusat, Propinsi,
Kabupaten dan Kota. Masing-masing pemerintahan daerah memiliki kebijaksanaannya sendiri-sendiri, dan sering tanpa memperhatikan sebagai komponen NKRI.

Ketiga, makna otonomi sebagai pemberian kewenangan pengelolaan daerah dipersempit oleh DPRD menjadi sekedar pengelolaan keuangan. Akibatnya ruang lingkup permasalahan dan aktivitas selalu dikaitkan dengan income. Disinilah praktek money politics mulai mempengaruhi DPRD mulai dari pencalonan sampai nantinya pada tahap pemberhentian sebagai anggota DPRD ataupun juga aktivitas-aktivitas lainnya yang berkaitan dengan adanya kewenangan di Badan Legislatif DPRD ini.

\section{Pemahaman Demokrasi}

Dengan ditetapkannya dan diundangkannya Undang-Undang Dasar 1945 Amandemen khususnya Pasal $6 \mathrm{~A}$ Ayat 1 dimana Pemilihan Presiden dan Wakil Presiden dilakukan dalam satu pasangan secara langsung oleh rakyat, meskipun masih dalam ruang lingkup dan makna demokrasi, tetap juga menimbulkan kebimbangan dan pertanyaan dari sebagian masyarakat terutama yang mendalami demokrasi. Apakah bagi Negara Indonesia sebagai negara kepulauan dengan kemajemukan SARA, melakukan pemilihan langsung seperti ini merupakan solusi keluar dari permasalahan kemelut politikpemerintahan ataukah justru akan menimbulkan permasalahan konstitusional atau lebih-lebih teknis administratif operasionalnya? Bagaimanakah mengaitkan ketentuan didalam Undang-Undang Dasar 1945 Amandemen yang menyatakan bahwa Indonesia menganut presidensiil (Kabinet Presidensiil) dengan prinsip atau azas parlementer? Apakah Civic Education dan Voter Information yang selama ini dilakukan 
telah membuat masyarakat "melek" Pemilihan Umum?

Belum sampai terjawab pertanyaanpertanyaan dimuka demikian juga dengan telah dimulainya proses pelaksanaan Pemilu secara nasional muncullah desakan dan keinginan untuk juga terjadinya Pemilihan secara langsung oleh masyarakat daerah bagi Kepala Daerahnya. Karena pemilihan Presiden dan Wakil Presidén akan dilakukan secara langsung pada Pemilu 2004, maka sebagian politisi menganggap pula sudah pada tempatnya penentuan Kepala Daerahpun dilakukan pemilihan secara langsung. Desakan dan tuntutan ini patut dipertanyakan pula, apakah sekedar reaksioner, emosional, situasional ataukah memang benar-benar telah dipikirkan dan dianalisa secara masak?

Situasi atau keberadaan tuntutan ini diperkuat juga oleh merebaknya dugaan permainan money politics yang terjadi tidak saja pada Pemilihan dan Penentuan Kepala Daerah yang selama ini diputuskan oleh DPRD, tetapi juga dalam pengangkatanpengangkatan ataupun aktivitas-aktivitas yang berkaitan diperlukannya persetujuan DPRD. Disamping juga aktivitas elite politik dan kekuasaan di daerah yang sangat mengkhawatirkan persatuan dan kesatuan sebagai NKRI (Negara Kesatuan Republik Indonesia).

Pertanyaan yang dapat dikemukakan lagi dalam hal ini adalah: pemilihan Kepala Daerah secara langsung sesungguhnya didalam kerangka apa? Apakah agar supaya kelihatan adanya proses demokrasi yang mantap dan Viable; apakah sekedar agar supaya dapat meningkatkan partisipasi dan kesadaran masyarakat daerah untuk menggunakan haknya; ataukah sekedar untuk menghilangkan money politics yang saat ini merebak dalam pemilihan dan pengangkatan pejabat daerah; ataukah sekedar untuk membatasi kekuasaan, kewenangan Badan Legislatip di daerah?

Proses demokrasi akan menjadi mulus dan tangguh dengan peningkatan kesadaran masyarakat apabila civic education dan informasi-informasi perpolitikan tersosialisasikan ke seluruh masyarakat. Politik bukanlah sekedar milik elit penguasa dan elit politik saja, tetapi juga harus menjadi milik masyarakat pula. Kematangan keseluruhan masyarakat dalam berpolitik khususnya Pemilu dan Pemilihan Kepala Daerah, tidak akan mempersoalkan pemilihan secara langsung ataupun tidak langsung. Tetapi dengan keberadaan masyarakat Indonesia terutama di daerahdaerah yang belum sadar berpolitik, pemilihan secara langsung akan menumbuhkan permasalahan. Dengan tingkat illiteracy yang tinggi dan tingkat sosiologis kebencian yang tinggi pula yang ada didalam masyarakat, maka akan terjadi permainan-permainan politik yang keluar dari tracks demokrasi. Antara lain pemaksaan, money politics dan kekerasan serta ancaman. Disamping keberadaan geografis dan administratif yang akan menyulitkan operasional pemilihan secara langsung.

Faktor lain yang harus dipertimbangkan adalah bahwa dalam pemilihan langsung Kepala Daerah maka rakyatlah yang akan bertambah bingung, yang justru akan menyebabkan rakyat terpecah belah. Di satu sisi akan membela DPRD-nya dimana rakyat yang memilihnya, tetapi disisi lain rakyat juga akan membela Kepala Daerahnya yang mereka pilih secara langsung. Disini keberadaan rakyat dapat dimainkan dan dipermainkan oleh DPRD dan Kepala Daerah. Demokrasi langsung malah akan menumbuhkan kesengsaraan rakyat daerah. Pemilihan Kepala Daerah secara langsung bukanlah solusi atau jalan keluar 
untuk memecahkan kemelut permasalahan politik dan pemerintahan di daerah. Ataupun juga untuk memecahkan permasalahan hubungan kekuasaan dan kewenangan diantara Pusat, Propinsi dengan Kabupaten ataupun Kota. Pemilihan secara langsung yang sekedar ditujukan untuk memperlihatkan suasana demokratis ataupun untuk menghilangkan money politics atau juga sekedar karena ditingkat nasional juga dilakukan pemilihan Presiden dan Wakil Presiden secara langsung, malahan akan menimbulkan kesulitan-kesulitan teknis, administratif dan operasional. Pada akhirnya nanti akan terjadinya juga penyelewengan dan pengingkaran akan makna demokrasi dan proses demokrasi (demokratisasi).

\section{Penutup}

Saat ini, yang paling penting adalah kesadaran dari elit politik maupun elit kekuasaan didalam Etika Berpolitik, dan kembalinya mereka kepada Core (misi, inti, fungsi)nya masing-masing. Disamping tidak menutup mata untuk menyadarkan masyarakat berpolitik dan berpemerintahan melalui kampanye Civic Education.

Bila kesemuanya ini disadari dan dimantapkan oleh semua pihak, meskipun pemilihan Kepala Daerah ataupun Pimpinan Nasional dilakukan secara tidak langsung, maka makna dan wujud demokrasi akan tetap nampak. Sehingga yang selama ini diduga bahwa didalam pemilihan secara tidak langsung terjadinya pat gulipat, main sabun, dagang sapi, pembagian roti kekuasaan, dengan kedewasaan berpolitik dan berpemerintahan melalui rules of the games yang disepakati didalam tingkat etika yang tinggi, hal-hal tersebut dapat dihindarkan,

\section{Daftar Pustaka}

Undang-Undang Nomor 22 Tahun 1999 Tentang :'emerintahan Daerah

Undang-Undang Nomor 25 Tahun 1999 Tentang Perimbangan Keuangan Antara Pemerintah Pusat dan Daerah

Peraturan Pemerintah Nomor 25 Tahun 2000 Tentang Kewenangan Daerah

Peraturan Pemerintah Nomor 84 Tahun 2000 Tentang Organisasi Perangkat Daerah

Peraturan Pemerintah Nomor 8 Tahun 2003 Tentang Organisasi Perangkat Daerah

Undang-Undang Dasar 1945 Amandemen

Undang-Undang Nomor 12 Tahun 2003 Tentang Pemilihan Umum Dewan Perwakilan Rakyat, Dewan Perwakilan Daerah dan Dewan Perwakilan Rakyat Daerah

Undang-Undang Nomor 23 tahun 2003 Tentang Pemilihan Umum Presiden dan Wakil Presiden. 